\title{
The Influence of Sensitivity Analysis on ohe Process of Price Decision Making and Pricing of the Company
}

\author{
Anna Kubjatkova ${ }^{1, *}$ \\ ${ }^{1}$ University of Zilina, Faculty of Operation and Economics of Transport and Communications, \\ Department of Economics, Univerzitna 1, 01026 Zilina, Slovakia
}

\begin{abstract}
.
Research background: An integral part of the existence of every company is the constant making of various decisions that affect the company and its surroundings on a global scale. These decisions include decisions about price, which is a key element of the company's interaction with its surroundings. In the conditions of globalization, price is a key factor in the competition, and price decisions must be made by the company very carefully and their selection is not easy. Sensitivity analysis helps companies choose the best options and steps in the price decision making, which will ultimately affect the process of pricing.

Purpose of the article: The purpose of this work is to point out the importance of sensitivity analysis as a tool for simplifying price decision making and to perform this analysis on a model example of a company.

Methods: Methods of analysis and research of the issue were used in the paper. Induction and deduction methods were also used to help provide a comprehensive picture of sensitivity analysis.

Findings \& Value added: The result of this work is, in addition to a general overview of the sensitivity analysis in price decision making, also the specific procedure and the results of the sensitivity analysis and recommendations for the company resulting from these results. Based on the created instructions, companies can make clear pricing decisions that will be of the greatest benefit to them.
\end{abstract}

Keywords: gross profit; price decision making; pricing; sensitivity analysis.

JEL Classification: $M 31$

*Corresponding author: anna.kubjatkova@,fpedas.uniza.sk 


\section{Introduction}

Over the course of their lives, companies will make a large number of price changes and pricing decisions. All these decisions affect not only the company itself, but also the surroundings of this company. Pricing as a process should provide the company with the most advantageous and best option that is beneficial to company. Price changes can be of various natures and often several changes can be made to achieve a positive result, but only some of them may be beneficial to company and only one may be most advantageous. Companies must therefore be aware of the impact of each change and, by quantifying this change, they can choose the one with the most economically advantageous impact.

Price changes have an impact not only on the company itself, but also on its suppliers and competitors. Price changes have the greatest impact on the company's customers. The fact is that the lower the price of a product or service, the more attractive the company is to the customer, but according to Chetthamrongchai and Saengchai [1], the perception of not only pricing strategy but also the quality of production and behavior affects the loyalty and devotion of the company's customers. According to Valaskova and Krizanova [2], the perception of quality criteria by the company is necessary in determining the motives for purchasing and customer loyalty. However, price changes still remain the biggest motive for purchasing, with loyal customers being key to the company's success. Customer loyalty is based not only on the price itself, but on the emotions and subjectively perceived sources of value of a particular brand, while the pricing itself can also be based on these sources $[3,4,5]$. Price decisions and price changes must also be adapted to the specific market and also to the socio-cultural profile of consumers. According to Kliestikova, Durana and Kovacova [6], the specifics of the national socio-cultural profile influence the value of the brand and thus also the devotion and loyalty of consumers. The perception of society by consumers is all the better the way a company and its brand have a profile similar to their home country. Therefore, price changes are often more sensitive to certain pricing decisions in different countries. The current price is influenced by a number of factors in each country, and the determination of a suitable price consists in finding out which specific factors influence this current price [7]. Knowledge of the business environment and strategic analysis of the customer are therefore as important for pricing decisions and subsequent price calculation as taking into account the company's costs and capabilities in price formation [8].

At present, when the goal of companies is no longer to maximize profits, but to maintain their position in the market and the associated growth of market share, strategic marketing and associated pricing are of great importance. The company's position on the market can be strengthened, among other things, by using various tools of modern marketing, which also includes green marketing, which according to Moravcikova, Krizanova, Kliestikova, Rypakova [9] has an impact on the company's market share. The company's market share is conditioned not only by brand building, but also by the right pricing decisions and price changes, the selection of which can be made using sensitivity analysis [10].

With the help of sensitivity analysis, it is possible to find out how an individual value affects the change of the final monitored value, according to which the decision is made. Factors that affect the final value can be divided into significant - in which the sensitivity of the final factor to these factors is significant, and insignificant - not so important ones. It is through sensitivity analysis that it is possible to reveal which factors are significant and which are insignificant with respect to a given pricing decision [11].

The sensitivity analysis is based on an explicit representation of the influence of risk factors on the effects of the project or profit, expressed, for example, by the profitability of the project or by market share. Knowledge of the dependence of profit or other criteria on 
risk factors, or other variables of a deterministic nature, then allows to determine the effects of changes in the values of risk factors, ie their negative or positive deviations from expected values on the size of profit or other evaluation criteria. When applying sensitivity analysis, it is possible to use computer support, in particular it is advantageous to use a spreadsheet. The advantage of sensitivity analysis is the possibility of expression in graphical form.

Before making a price decision and performing a sensitivity analysis, the company needs to carry out the market research necessary to identify customers' needs in terms of price itself. Regular monitoring of customers' needs in the field of obtaining information for complex pricing decisions can be considered as a competitive advantage, which can be decisive in the competition. Consumers' attitudes towards private labels also influence price formation and pricing decisions [12]. There can be a lot of information that a company works with when making pricing decisions.

Pricing is key to the pricing process, and any pricing decision can have a positive or negative impact on the business. An analysis of the current situation as well as the legislative environment is also needed to perform a sensitivity analysis [13]. Based on the results of the sensitivity analysis, the company can therefore choose the price decision that will have the best economic impact for it and will be feasible on its part. Pricing decisions are part of a marketing strategy that Kicova and Nadanyiova [14] say may be key to a company's success in competing in the market.

\section{Methods}

To perform a sensitivity analysis, the company needs to identify certain elements such as the final factor, key variables and also must follow certain steps of the analysis process.

\subsection{The final factor}

Sensitivity analysis is very important in the pricing process, because it helps companies with the necessary pricing decisions, which will ultimately affect the company's own pricing. In the pricing process, sensitivity analysis is used as a way to reduce some uncertainty. Companies need to determine the final factor that will be involved in the decision-making process itself. Price decisions mainly concern the amount of the company's gross profit, but there are cases where the decisions also concern the net present value, the amount of costs, sales price, amount of investment and others.

\subsection{Key variables}

In order to perform a sensitivity analysis, the input data, ie the most probable values of the risk factors, are necessary, and these are their most accurate estimates. A necessary condition for performing a sensitivity analysis is the interdependence of these input data. If the input data are not interdependent, performing a sensitivity analysis is irrelevant.

\subsection{Sensitivity analysis process}

The process of sensitivity analysis in pricing can be divided into several steps. First, the company must determine the final factor, ie the observed value, which is usually gross profit. Next, it is necessary to identify the key variables that have a significant effect on the value of the final factor. The following is a calculation of the effects of changes in these variables on the value of the final factor. The next step is to analyze the magnitude of the 
changes, examining the relevance and justification of the changes made. Finally, a possible combination of variables and their effect on the value of the final factor is analyzed [15].

The result of the sensitivity analysis is the exact answer to the question of which key variables have the largest and most significant impact on the value of the final factor.

\section{Results}

To perform a sensitivity analysis, we present a model example of Company $\mathrm{X}$ when the company tries to find out how the amount of its gross profit (GP) will change, the criteria being as follows: $10 \%$ reduction in variable costs, increase in the number of products placed on the market by 200 pieces, reduction of fixed costs by $5 \%$, increase of the selling price per piece by $15 \%$.

Key variables are needed to perform the analysis. The company manufactures certain products and supplies them to the market in quantities of (Q) 3,000 pieces, which represents a market share (MS) of $20 \%$. The selling price (P) of these products is $150 €$ per piece. Variable costs (VC) per piece are $40 €$ and fixed costs (FC) for the entire production volume are $18,000 €$.

It is best to perform a sensitivity analysis using a table, where we always capture the change of one key variable with the other unchanged variables. In the table, the values are rounded up to whole numbers. It will then be clear from the results which variable most affected the amount of the company's gross profit.

Table 1. Impact of key variables on gross profit.

\begin{tabular}{|c|c|c|c|c|c|}
\hline & $\begin{array}{c}\text { Original } \\
\text { values }\end{array}$ & $\begin{array}{c}10 \% \\
\text { reduction in } \\
\text { variable costs }\end{array}$ & $\begin{array}{l}\text { Increase the } \\
\text { number of } \\
\text { products } \\
\text { placed on the } \\
\text { market by } \\
200 \text { pieces }\end{array}$ & $\begin{array}{c}\text { Reduction of } \\
\text { fixed costs by } \\
5 \%\end{array}$ & $\begin{array}{c}\text { Increase the } \\
\text { selling price } \\
\text { per piece by } \\
15 \%\end{array}$ \\
\hline $\mathbf{Q}$ (in pieces) & 3,000 & 3,000 & 3,200 & 3,000 & 3,000 \\
\hline MS (\%) & 20 & 20 & 22 & 20 & 20 \\
\hline$P(€ /$ piece $)$ & 150 & 150 & 150 & 150 & 173 \\
\hline Sales (€) & 450,000 & 450,000 & 480,000 & 450,000 & 519,000 \\
\hline VC (€/piece) & 40 & 36 & 40 & 40 & 40 \\
\hline$F C(€)$ & 18,000 & 18,000 & 18,000 & 17,100 & 18,000 \\
\hline$C(€)$ & 138,000 & 126,000 & 138,000 & 137,100 & 138,000 \\
\hline GP (€) & 312,000 & 324,000 & 342,000 & 312,900 & 381,000 \\
\hline
\end{tabular}

Source: processed by the authors

In Table 1 we can see that the biggest impact on the amount of the company's gross profit has an increase in the selling price of the product by $15 \%$, which is an increase of up to $69,000 €$. In practice, however, these are isolated cases where, for example, the products have no competition, or when the products are luxury goods. Therefore, this option may not be available for Company X. Thus, assuming that a change in the selling price would not be possible, the company should focus on increasing the number of products by 200 pieces. This is the key variable that has the second largest impact on gross profit. The company should therefore look for new customers and new opportunities to sell another 200 pieces of products, which would increase the company's gross profit by $30,000 €$. It is also clear from the table that reducing fixed and variable costs would not have the same effect on increasing gross profit as on the other two key variables, so the company will not consider them as suitable alternatives when making price decisions. 


\section{Discussions}

Sensitivity analysis is undoubtedly a useful tool for companies in the pricing process. As part of this analysis, companies will determine which of the identified options is most advantageous for them, ie which company will influence as positively as possible.

However, in order to use sensitivity analysis, a company must be well aware of its economic situation and consider such price changes and decisions that can be made in real life. It is essential for a company to be able to enforce a given pricing decision, so it must plan all pricing decisions accurately and use all available information to avoid pricing decisions that are unrealistic or would impede the pricing process and harm the company's economic health. Therefore, through the company's sensitivity analysis, companies will identify specific impacts on their profitability or market share and it is up to them to apply these pricing decisions for their own development.

This paper is an output of scientific project VEGA no. 1/0718/18: The impact of psychographic aspects of pricing on the marketing strategy of companies across products and markets.

\section{References}

1. Chetthamrongchai, P., Saengchai, S. (2019). The impact of perceived service quality, customer perception and price strategy on pharmacy customer devotion. Polish Journal of Management Studies, 20(1), 139-148.

2. Valaskova, M., Krizanova, A. (2008). The passenger satisfaction survey in the regional integrated public transport system. Promet-Traffic \& Transportation, 20(6), 401-404.

3. Kliestikova, J., Kovacova, M., Krizanova, A., Durana, P., Nica, E. (2019). Quo vadis brand loyalty?: Comparative study of perceived brand value sources. Polish Journal of Management Studies, 19(1), 190-203.

4. Nadanyiova, M. (2017). Neuromarketing - An opportunity or a threat? Communications: Scientific Letters of the University of Žilina, 19(4), 90-94.

5. Palus, H., Matova, H., Krizanova, A., Parobek, J. (2014). A survey of awareness of forest certification schemes labels on wood and paper products. Acta Facultatis Xylologiae Zvolen, 56(1), 129-138.

6. Kliestikova, J., Durana, P., Kovacova, M. (2019). Naked Consumer's Mind Under Branded Dress: Case Study of Slovak Republic. Central European Business Review, 8(1), 15-32.

7. Dengov, V., Tulyakova, I., Gregova, E., Sviridov, G. (2020). Price strategies of mobile operators in Russia in the conditions of the global economic recession. Oeconomia Copernicana, 11(2), 347-370.

8. Krylov, S. (2019). Strategic customer analysis based on balanced scorecard. Ekonomicko-manazerske spektrum, 13(1), 12-25.

9. Moravcikova, D., Krizanova, A., Kliestikova, J., Rypakova, M. (2017). Green marketing as the source of the competitive advantage of the business. Sustainability, 9(12), 2218.

10. Majerova, J., Kliestik, T. (2015). Brand valuation as an immanent component of brand value building and managing. Proceedings of the 4th World Conference on Business, Economics and Management (pp. 546-552). Zilina: Univ Zilina, Fac Operation \& Economics Transport \& Communication.

11. Scholleova, H. (2009). Investment controlling. Bratislava : Grada Publishing. 
12. Valaskova, K., Kliestikova, J., Krizanova, A. (2018). Consumer perception of private label products: An empirical research. Journal of Competitiveness, 10(3), 149-163.

13. Krizanova, A. (2008). The current possition and perspecives of the integrated transport systems in Slovak Republic. Eksploatacja I Niezawodnosc-Maintenance and Reliability, (4), 25-27.

14. Kicova, E., Nadanyiova, M. (2015). Marketing strategies in bus transport companies and its impact on increasing the competitiveness. Proceedings of the 15th International Scientific Conference on Globalization and its Socio-Economic Consequences (pp. 292-296). Zilina: Univ Zilina, Fac Operation \& Economics Transport \& Communication.

15. Kufelova, I. (2017). Prices and price decision making. Bratislava : Wolters Kluwer. 